\title{
KESADARAN HUKUM MASYARAKAT TERHADAP KEPEMILIKAN AKTA PERKAWINAN BERDASARKAN UNDANG-UNDANG NO. 1 TAHUN 1974 (STUDI PADA MASYARAKAT DI BANJAR PASTI)
}

\author{
Oleh \\ Ayu Putu Laksmi Danyathi \\ Universitas Udayana \\ Email : gektini2014@gmail.com
}

\begin{abstract}
Indonesia as a State of Law, has some rules about marriage that is Law Number 1 Year 1974. Marriage is legitimate if it is according to the laws of their each religion and belief. Furthermore, there is also an obligation to register their marriage. Pasti is the name of a banjar that located in Pandak Gede Village, Kediri District, Tabanan Regency, Province of Bali. To prove that the marriage existed, Pasti's citizens must have a Marriage Act.

This research aims to determine the level of community legal awareness in Banjar Pasti on marriage certificate ownership, and to know and examine the factors that affect it. This research uses empirical juridical approach method, that is using the existing factual approach by way of observation and research in the field, then studied and reviewed based on relevant legislation as a reference to solve the problem.

Based on the research, it is found that the level of community legal awareness in Banjar Pasti on marriage certificate ownership based on Law Number 1 Year 1974 regarding Marriage is relatively high. This can be proved by the following indicators : (a). The high level of community law knowledge in Banjar Pasti on marriage certificate ownership. (b). The high level of community law understanding in Banjar Pasti on marriage certificate ownership. (c). The high level of community legal attitude in Banjar Pasti on marriage certificate ownership. (d). The high level of community legal behavior patterns in Banjar Pasti on marriage certificate ownership. The Factors influencing the community legal awareness in Banjar Pasti on marriage certificate ownership under Law Number 1 Year 1974 regarding Marriage, that is : Level of education, Age and Sex.
\end{abstract}

Keywords : Marriage, Marriage Act, Legal awareness.

\section{PENDAHULUAN}

Perkawinan merupakan suatu peristiwa yang sangat penting dalam kehidupan manusia. Perkawinan mempunyai arti penting dalam kehidupan manusia, karena didalamnya ada unsur hak dan kewajiban antara masing-masing pihak, menyangkut masalah kehidupan kekeluargaan yang harus dipenuhi, baik hak dan kewajiban suami isteri maupun keberadaan status perkawinan, anakanak, kekayaan, waris dan faktor kependudukan di dalam tatanan kehidupan bermasyarakat.
Indonesia sebagai Negara Hukum, mempunyai peraturan yang mengatur tentang perkawinan yakni Undang-undang Nomor 1 Tahun 1974 (selanjutnya disebut Undang-Undang Perkawinan). Di dalam Undang-Undang Perkawinan telah ditentukan bahwa Perkawinan adalah sah apabila dilakukan menurut hukum masing-masing agamanya dan kepercayaannya itu. Selanjutnya ditentukan pula adanya kewajiban untuk mencatatkan perkawinannya, sehingga 
diperoleh bukti tentang adanya perkawinan yaitu Akta Perkawinan yang telah dibukukan dalam register catatan sipil.

Akta perkawinan merupakan suatu bukti tentang adanya peristiwa Perkawinan. Akta perkawinan tersebut telah dibukukan dalam register-register pencatatan sipil. Hal tersebut telah diatur dalam ketentuan Pasal 100 KUHPerdata. Pada masa yang lalu, pembuat undang-undang (KUHPerdata) memandang soal perkawinan hanya dalam hubungan-hubungan perdatanya saja, yang diartikan hanya mengakuinya, kalau dilaksanakan di hadapan Pegawai Pencatatan Sipil. Saat ini, dengan dikeluarkannya UndangUndang Perkawinan. Sahnya perkawinan diakui, jika telah dilaksanakan sesuai dengan hukum agamanya masing-masing, maka pencatatan hanya merupakan tindakan administratif saja. Akta Perkawinan merupakan akta autentik, sehingga mempunyai daya pembuktian yang sempurna dengan segala konsekuensinya, demikian sebagaimana dirumuskan oleh Rachmadi Usman. Bali merupakan sebuah pulau yang menjadi tujuan wisatawan dari seluruh dunia, dimana masyarakatnya hidup berdampingan secara harmonis. Desa Pandak Gede adalah salah satu desa dari 15 desa di Kecamatan Kediri, Kabupaten Tabanan yang merupakan daerah landai dengan ketinggian 250 meter diatas permukaan laut, dengan curah hujan relatif rendah, dengan batas wilayah administratif sebagai berikut: - Sebelah Utara berbatasan dengan : Desa Pandak

Bandung

-Sebelah Timur berbatasan dengan : Sungai Yeh Sungi

- Sebelah Selatan berbatasan dengan : Desa Beraban

- Sebelah Barat berbatasan dengan : Yeh Kutikan

Desa Pandak Gede mempunyai Luas wilayah $4.29 \mathrm{~km} 2$ / 429.000 M2 (berdasarkan Peraturan Bupati Tabanan nomor 29 Tahun 2005 tentang Kode dan Data Wilayah Administrasi Pemerintahan Kabupaten Tabanan). Desa Pandak Gede mewilayahi 8 (delapan) Banjar Dinas, yaitu : Banjar Dinas Batanpoh, Banjar Dinas Pangkung, Banjar Dinas Saba, Banjar Dinas Belatung, Banjar Dinas Panti, Banjar Dinas Tamansari, Banjar Dinas Kebon, Banjar Dinas Pasti. Berdasarkan hasil sensus pada tahun 2010 Desa Pandak Gede mempunyai Penduduk sebanyak 5178 jiwa, terdiri dari 2537 laki-laki dan 2641 perempuan, dengan $1435 \mathrm{KK}$.

Pasti merupakan salah satu Banjar Dinas yang menjadi bagian dari wilayah Desa Pandak Gede, yang letaknya paling selatan di jalur Kawasan Obyek Pariwisata Tanah Lot. Secara geografis Banjar Pasti termasuk daerah pertanian dengan mayoritas tanaman padi disamping tegalan dengan aneka tanamannya. Masyarakat Banjar Pasti dahulu sebagian besar menggantungkan kehidupannya pada sektor pertanian, kini telah berkembang mengikuti perkembangan jaman sehingga terjadilah pergeseran dari pertanian ke sektor dagang dan jasa.

Masyarakat di Banjar Pasti merupakan masyarakat yang heterogen, terdiri dari $108 \mathrm{KK}$. Ketika akan dilaksanakan suatu Perkawinan, maka masyarakat Banjar Pasti sudah seharusnya mentaati peraturan hukum yang telah ada yaitu Undang-Undang Perkawinan. Untuk membuktikan bahwa peristiwa perkawinan itu ada, maka masyarakat Banjar Pasti harus memiliki Akta Perkawinan. Kepemilikan Akta Perkawinan ini menunjukkan bahwa peristiwa perkawinan itu telah dicatatkan di Dinas Kependudukan dan Pencatatan Sipil.

Di bidang hukum keluarga khususnya perkawinan, masyarakat Banjar Pasti sudah ada yang telah memiliki Akta Perkawinan. Untuk memperoleh akta perkawinan ini, mereka harus memenuhi berbagai persyaratan yang telah ditentukan oleh Dinas Kependudukan dan Pencatatan Sipil Kabupaten Tabanan. Di sisi lain masyarakat di Banjar Pasti ada juga yang belum memiliki Akta Perkawinan, sebagai bukti adanya suatu peristiwa perkawinan. Hal tersebut tentu saja tidak sesuai dengan ketentuan Pasal 2 ayat (2) Undang-Undang Perkawinan, dimana suatu peristiwa perkawinan yang telah dilaksanakan secara sah menurut hukum agama, harus pula dicatatkan di Dinas Kependudukan dan Pencatatan Sipil. Hal ini terkait dengan masalah kesadaran hukum masyarakat Banjar Pasti.

Melihat situasi dan kondisi masyarakat di Banjar Pasti, diharapkan adanya kerjasama antara masyarakat dan aparat pemerintah dalam upaya untuk meningkatkan pengetahuan dan pemahaman masyarakat akan pentingnya kepemilikan Akta 
Perkawinan. Dengan demikian perlu dilaksanakan penelitian yang bertujuan untuk mengetahui tingkat kesadaran hukum masyarakat di Banjar Pasti terhadap kepemilikan Akta Perkawinan, mengetahui dan mengkaji faktor-faktor yang mempengaruhi kesadaran hukum masyarakat di Banjar Pasti terhadap kepemilikan Akta Perkawinan sehingga dapat dilakukan segera penanganan lebih lanjut.

\section{HASIL DAN PEMBAHASAN}

A.Tingkat Kesadaran Hukum Masyarakat di Banjar Pasti terhadap Kepemilikan Akta Perkawinan berdasarkan Undang-Undang Perkawinan

Berbicara mengenai kesadaran hukum tidak terlepas dari indikator kesadaran hukum. Indikator itu yang nantinya akan berpengaruh besar terhadap kesadaran hukum. Menurut Soerjono Soekanto, kesadaran hukum adalah konsepsikonsepsi abstrak di dalam diri manusia, tentang keserasian antara ketertiban dengan ketentraman yang dikehendaki atau sepantasnya. Masyarakat dalam hal ini yang nantinya akan mengefektifkan hukum yang berlaku, sehingga untuk memperoleh hasil tentang tingkat kesadaran hukum masyarakat di Banjar Pasti terhadap kepemilikan akta perkawinan dapat dilakukan dengan mengetahui nilai dari masing-masing indikator. Indikatorindikator dari masalah kesadaran hukum tersebut adalah :

1. Pengetahuan tentang peraturan-peraturan hukum;

2. Pengetahuan tentang isi peraturan-peraturan hukum;

3. Sikap terhadap peraturan-peraturan hukum;

4. Pola-pola perikelakuan hukum

Apabila indikator-indikator tersebut dikaitkan dengan tingkat kesadaran hukum masyarakat Di Banjar Pasti terhadap kepemilikan akta perkawinan, maka dapat dirumuskan bahwa kesadaran hukum masyarakat dapat diukur dengan indikator-indikator yang ditetapkan, antara lain : indikator pengetahuan hukum masyarakat terhadap kepemilikan akta perkawinan, pemahaman hukum masyarakat terhadap kepemilikan akta perkawinan, sikap hukum masyarakat terhadap kepemilikan akta perkawinan, serta pola perilaku hukum masyarakat terhadap kepemilikan akta perkawinan.

Tingkat masing-masing indikator kesadaran hukum tersebut dapat diketahui dengan mengajukan pertanyaan kepada seluruh responden. Pertanyaan yang diajukan kepada responden sebanyak 12 pertanyaan tentang kesadaran hukum yang terdiri dari unsur pengetahuan sebanyak 3 pertanyaan, unsur pemahaman hukum sebanyak 3 pertanyaan, unsur sikap hukum sebanyak 3 pertanyaan, unsur pola prilaku hukum sebanyak 3 pertanyaan. Kemudian setiap pertanyaan tersebut nantinya akan diberi nilai antara 1-3 berdasarkan jawaban yang diberikan oleh responden. Nilai masing-masing indikator kesadaran hukum menurut 30 responden dapat dilihat dalam tabel dibawah ini :

Tabel 1 : Distribusi nilai masing-masing indikator kesadaran hukum, nilai kesadaran hukum, tingkat pendidikan, umur dan jenis kelamin responden.

\begin{tabular}{|c|c|c|c|c|c|c|c|c|}
\hline No & $\begin{array}{l}\text { Pgt } \\
\text { Hkm }\end{array}$ & $\begin{array}{l}\text { Pmhmn } \\
\text { Hkm }\end{array}$ & $\begin{array}{l}\text { Sikap } \\
\text { Hkm }\end{array}$ & $\begin{array}{l}\text { Prlku } \\
\text { Hkm }\end{array}$ & $\begin{array}{l}\text { Ksdrn } \\
\text { Hkm }\end{array}$ & $\begin{array}{l}\text { Tingkat } \\
\text { Pendidikan }\end{array}$ & \begin{tabular}{|l|} 
Umur \\
(Thn.)
\end{tabular} & $\begin{array}{l}\text { Jenis } \\
\text { Kelamin }\end{array}$ \\
\hline 1 & 9 & 9 & 8 & 9 & 35 & SMA & \begin{tabular}{|l|}
48 \\
\end{tabular} & $\mathrm{~L}$ \\
\hline 2 & 8 & 9 & 8 & 9 & 34 & SMP & 51 & $P$ \\
\hline 3 & 9 & 9 & 8 & 9 & 35 & SMA & 35 & $\mathrm{~L}$ \\
\hline 4 & 7 & 9 & 99 & 9 & 34 & SMA & 34 & L \\
\hline 5 & 8 & 9 & 8 & 9 & 34 & SMA & 47 & $\mathrm{~L}$ \\
\hline 6 & 6 & 8 & 9 & 8 & 31 & SMA & 34 & L \\
\hline 7 & 6 & 8 & 9 & 9 & 32 & SMA & 45 & L \\
\hline 8 & 7 & 9 & 9 & 9 & 34 & SMA & \begin{tabular}{|l|}
48 \\
\end{tabular} & $\mathrm{~L}$ \\
\hline 9 & 6 & 7 & 4 & 6 & 23 & SMA & 52 & $P$ \\
\hline 10 & 7 & 9 & 8 & 9 & 33 & SMA & 24 & $\mathrm{~L}$ \\
\hline 11 & 7 & 7 & 7 & 6 & 27 & SMA & 37 & $\mathrm{P}$ \\
\hline 12 & 5 & 5 & 4 & 6 & 20 & SMA & 35 & $\mathrm{~L}$ \\
\hline 13 & 7 & 7 & 9 & 9 & 32 & SMP & \begin{tabular}{|l|}
40 \\
\end{tabular} & $\mathrm{P}$ \\
\hline 14 & 8 & 9 & 9 & 9 & 35 & SMA & 39 & $P$ \\
\hline 15 & 8 & 8 & 9 & 9 & 34 & SMA & 29 & $P$ \\
\hline 16 & 9 & 9 & 6 & 9 & 33 & PT & 31 & $P$ \\
\hline 17 & 6 & 8 & 9 & 9 & 32 & SD & 53 & $\mathrm{P}$ \\
\hline 18 & 9 & 9 & 9 & 9 & 36 & SMA & 35 & $\mathrm{P}$ \\
\hline 19 & 6 & 6 & 7 & 9 & 28 & PT & 43 & $\mathrm{~L}$ \\
\hline No & $\begin{array}{l}\text { Pgt } \\
\text { Hkm }\end{array}$ & $\begin{array}{l}\text { Pmhmn } \\
\mathrm{Hkm}\end{array}$ & $\begin{array}{l}\text { Skp } \\
\text { Hkm }\end{array}$ & $\begin{array}{l}\text { Prlku } \\
\mathrm{Hkm}\end{array}$ & $\begin{array}{l}\text { Ksdrn } \\
\text { Hkm }\end{array}$ & $\begin{array}{l}\text { Tingkat } \\
\text { Pendidikan }\end{array}$ & $\begin{array}{l}\text { Umur } \\
\text { (Thn.) }\end{array}$ & $\begin{array}{l}\text { Jenis } \\
\text { Kelamin }\end{array}$ \\
\hline 20 & 5 & 5 & 9 & 9 & 28 & SD & 43 & $\mathrm{P}$ \\
\hline 21 & 8 & 7 & 8 & 9 & 32 & SMP & \begin{tabular}{|l|}
48 \\
\end{tabular} & L \\
\hline 22 & 7 & 8 & 9 & 9 & 33 & SD & 46 & $\mathrm{P}$ \\
\hline 23 & 7 & 7 & 9 & 8 & 31 & SMA & 25 & $\mathrm{P}$ \\
\hline 24 & 9 & 9 & 7 & 8 & 33 & PT & 24 & $P$ \\
\hline 25 & 9 & 9 & 7 & 9 & 34 & SMA & 30 & $\mathrm{P}$ \\
\hline 26 & 8 & 9 & 8 & 9 & 34 & SMA & 43 & $P$ \\
\hline 27 & 9 & 9 & 8 & 9 & 35 & SMA & 34 & $P$ \\
\hline
\end{tabular}

Sumber: Data primer yang diolah. 
Keterangan :

- Pgt Hkm : Pengetahuan Hukum

- Pmhmn Hkm : Pemahaman Hukum

- Skp Hkm : Sikap Hukum

- Prlku Hkm : Perilaku Hukum

- Ksdrn Hkm : Kesadaran Hukum

- SD

- SMP

- SMA

- PT

: Sekolah Menengah Pertama

: Sekolah Menengah Atas

: Perguruan Tinggi

Berdasarkan tabel tersebut diatas, dapat diketahui variabel kesadaran hukum dengan indikator pengetahuan hukum, pemahaman hukum, sikap hukum dan pola perilaku hukum. Untuk mengklasifikasikan variabel kesadaran hukum dan indikatornya sebagaimana dipaparkan dalam tabel diatas diperhitungkan interval klas pada masingmasing nilai (skor) variabel dan indikator tersebut, dengan rumus sebagai berikut:

$\mathrm{i}=\underline{\mathrm{R}}$

$\mathrm{K}$

Dimana :

i : interval klas yang dikehendaki.

$\mathrm{R}$ : range yang merupakan simbol pengurangan nilai tertinggi dikurangi nilai terendah.

$\mathrm{K}$ : klas yang dikehendaki dalam setiap variabel dan indikator yang dapat dinyatakan dalam 3 klas, yaitu rendah, sedang, tinggi. (rumus dikutip dari tulisan Tanty Kusuma Digdani)

Berdasarkan perhitungan dengan menggunakan rumus tersebut diatas, maka diperoleh interval kelas pada masing-masing variabel dan indikator sebagai berikut :

a. Kesadaran hukum, yang dapat dinyatakan dalam kesadaran hukum rendah, sedang dan tinggi, dengan interval klas sebagai berikut :

- Nilai 20-24 adalah rendah;

- Nilai 25-30 adalah sedang;

- Nilai 31-36 adalah tinggi.

b. Indikator pengetahuan hukum, yang dapat dinyatakan dalam pengetahuan hukum rendah, sedang dan tinggi, dengan interval klas sebagai berikut:

- Nilai 5-6 adalah rendah

- Nilai 7 adalah sedang

- Nilai 8-9 adalah tinggi

c. Indikator pemahaman hukum, yang dapat dinyatakan dalam pemahaman hukum rendah,

sedang dan tinggi, dengan interval klas sebagai berikut :

- Nilai 5-6 adalah rendah

- Nilai 7 adalah sedang

- Nilai 8-9 adalah tinggi

d. indikator sikap hukum, yang dapat dinyatakan dalam sikap hukum tidak setuju, kurang setuju, dan setuju, dengan interval klas sebagai berikut:

- Nilai 4-5 adalah tidak setuju

- Nilai 6-7 adalah kurang setuju

- Nilai 8-9 adalah setuju

e. Indikator pola perilaku hukum, yang dapat dinyatakan dalam pola perilaku hukum tidak sesuai, kurang sesuai dan sesuai, dengan interval klas sebagai berikut :

- Nilai 6 adalah tidak sesuai

- Nilai 7 adalah kurang sesuai

- Nilai 8-9 adalah sesuai

Untuk mengetahui tingkat kesadaran hukum masyarakat Banjar Pasti terhadap kepemilikan akta perkawinan, hasil penelitian secara umum menggambarkan tingkat kesadaran hukum yang tinggi, hal ini dapat dibuktikan dengan melihat data yang dituangkan dalam tabel dibawah ini:

Tabel 2 : Kesadaran hukum responden terhadap kepemilikan akta perkawinan.

\begin{tabular}{|c|c|c|c|}
\hline $\begin{array}{c}\text { Kesadaran } \\
\text { Hukum }\end{array}$ & $\begin{array}{c}\text { Interval } \\
\text { Klas }\end{array}$ & $\begin{array}{c}\text { Frekuensi } \\
(\mathbf{F})\end{array}$ & $\begin{array}{c}\text { Persentase } \\
\mathbf{( \% )}\end{array}$ \\
\hline Rendah & $20-24$ & 2 & 6.67 \\
Sedang & $25-30$ & 3 & 10 \\
Tinggi & $31-36$ & 25 & 83,33 \\
\hline Jumlah & & 30 & 100 \\
\hline
\end{tabular}

Sumber : Data primer yang diolah.

Tabel 2 diatas menjelaskan bahwa dari seluruh responden sebanyak 30 orang, sejumlah $2(6,67 \%)$ responden mempunyai tingkat kesadaran hukum yang relatif rendah terhadap kepemilikan akta perkawinan, sejumlah 3 (10\%) responden mempunyai tingkat kesadaran hukum yang relatif sedang terhadap kepemilikan akta perkawinan, dan sejumlah $25(83,33 \%)$ responden mempunyai kesadaran hukum yang relatif tinggi terhadap kepemilikan akta perkawinan.

Tingginya tingkat kesadaran hukum terhadap kepemilikan akta perkawinan tidak terlepasa dengan tingkat pengetahuan hukum, 
pemahaman hukum, sikap hukum dan pola prilaku hukumnya.

Apabila kesadaran hukum masyarakat terhadap kepemilikan akta perkawinan dilihat dari indikator pengetahuan hukum, maka diperoleh gambaran sebagaimana yang terdapat dalam tabel berikut:

Tabel 3 : pengetahuan hukum responden terhadap kepemilikan akta perkawinan

\begin{tabular}{|c|c|c|c|}
\hline $\begin{array}{c}\text { Pengetahuan } \\
\text { Hukum }\end{array}$ & Interval Klas & $\begin{array}{c}\text { Frekuensi } \\
(\mathrm{F})\end{array}$ & Presentase \\
\hline Rendah & $5-6$ & 7 & 23,33 \\
Sedang & 7 & 7 & 23,33 \\
Tinggi & $8-9$ & 16 & 53,33 \\
& & & \\
\hline Jumlah & & 30 & 100 \\
\hline
\end{tabular}

Sumber : Data primer yang diolah.

Tabel 3 diatas menjelaskan bahwa dari seluruh responden sebanyak 30 orang, sejumlah $7(23,33 \%)$ responden mempunyai tingkat pengetahuan hukum yang relatif rendah terhadap kepemilikan akta perkawinan. Sejumlah 7 $(23,33 \%)$ responden mempunyai tingkat pengetahuan hukum yang relatif sedang terhadap kepemilikan akta perkawinan. Sejumlah 16 $(53,33 \%)$ responden mempunyai tingkat kesadaran hukum yang relatiftinggi terhadap kepemilikan akta perkawinan.

Berdasarkan data diatas dapat diambil kesimpulan bahwa sebagian besar masyarakat Banjar Pasti, Desa Pandak Gede, Kabupaten Tabanan, memiliki tingkat pengetahuan hukum yang tinggi terhadap kepemilikan akta perkawinan.

Menurut Otje Salman indikator pertama dari kesadaran hukum adalah pengetahuan hukum. Seseorang mengetahui bahwa perilaku-perilaku tertentu itu telah diatur oleh hukum. Peraturan hukum yang dimaksud disini adalah hukum tertulis maupun hukum yang tidak tertulis. Perilaku tersebut menyangkut perilaku yang dilarang oleh hukum maupun perilaku yang diperbolehkan oleh hukum.

Kesadaran hukum masyarakat terhadap kepemilikan akta perkawinan juga dapat dilihat dari indikator pemahaman hukum, maka diperoleh gambaran sebagaimana yang terdapat dalam tabel berikut:
Tabel 4 : Pemahaman hukum responden terhadap kepemilikan akta perkawinan.

\begin{tabular}{|c|c|c|c|}
\hline $\begin{array}{c}\text { Pemahaman } \\
\text { Hukum }\end{array}$ & Interval Klas & $\begin{array}{c}\text { Frekuensi } \\
(\mathrm{F})\end{array}$ & $\begin{array}{c}\text { Presentase } \\
(\%)\end{array}$ \\
\hline Rendah & $5-6$ & 4 & 13,33 \\
Sedang & 7 & 6 & 20 \\
Tinggi & $8-9$ & 20 & 66,67 \\
\hline Jumlah & & & 100 \\
\hline
\end{tabular}

Sumber : Data primer yang diolah.

Tabel 4 diatas menjelaskan bahwa dari seluruh responden sebanyak 30 orang, sejumlah $4(13,33 \%)$ responden mempunyai tingkat pemahaman hukum yang relatif rendah terhadap kepemilikan akta perkawinan. Sejumlah 6(20\%) responden mempunya tingkat pemahaman hukum yang relatif sedang terhadap kepemilikan akta perkawinan, dan sejumlah $20(66,67 \%)$ responden mempunyai tingkat pemahaman hukum yang relatif tinggi terhadap kepemilikan akta perkawinan.

Berdasarkan data tersebut diatas dapat diambil kesimpulan bahwa sebagian besar masyarakat Banjar Pasti, Desa Pandak Gede, Kabupaten Tabanan memiliki tingkat pemahaman hukum yang tinggi terhadap kepemilikan akta perkawinan. Apabila dihubungkan data yang terdapat pada tabel 4 dengan tabel 3, maka dapat diinterpretasikan bahwa tingginya pemahaman hukum tersebut didasarkan pada pengetahuan hukum masyarakat yang tinggi terhadap kepemilikan akta perkawinan.

Menurut Otje Salman, indikator kedua dari kesadaran hukum adalah pemahaman hukum, yaitu sejumlah informasi yang dimiliki seseorang mengenai isi peraturan dari suatu hukum tertentu. Pemahaman hukum disini adalah suatu pengertian terhadap isi dan tujuan suatu peraturan dalam hukum tertentu serta manfaatnya bagi pihak-pihak yang kehidupannya diatur oleh peraturan tersebut. Seorang warga masyarakat mempunyai pengetahuan dan pemahamannya masing-masing mengenai aturan-aturan tertentu, misalnya adanya pengetahuan dan pemahaman yang benar mengenai pentingnya Undang-Undang Nomor 1 Tahun 1974 tentang Perkawinan. Pemahaman ini diwujudkan melalui sikap mereka terhadap tingkah laku sehari-hari.

Kesadaran hukum masyarakat terhadap kepemilikan akta perkawinan selain dilihat dari 
pemahaman hukum juga dapat dilihat dari indikator sikap hukum, maka diperoleh gambaran sebagaimana yang terdapat dalam tabel berikut:

Tabel 5 : Sikap hukum responden terhadap kepemilikan akta perkawinan.

\begin{tabular}{|c|c|c|c|}
\hline $\begin{array}{c}\text { Sikap } \\
\text { Hukum }\end{array}$ & $\begin{array}{c}\text { Interval } \\
\text { Klas }\end{array}$ & $\begin{array}{c}\text { Frekuensi } \\
(\mathrm{F})\end{array}$ & $\begin{array}{c}\text { Presentase } \\
(\%)\end{array}$ \\
\hline Tidak Setuju & $4-5$ & 2 & 6,66 \\
Kurang Setuju & $6-7$ & 5 & 16,67 \\
Setuju & $8-9$ & 23 & 76,67 \\
& & & 100 \\
\hline Jumlah & & 30 & \\
\hline
\end{tabular}

Sumber : Data primer yang diolah.

Tabel 5 diatas menjelaskan bahwa dari seluruh responden sebanyak 30 orang, sejumlah $2(6,66 \%)$ responden mempunyai tingkat sikap hukum yang relatif tidak setuju terhadap kepemilikan akta perkawinan. Sejumlah 5 $(16,67 \%)$ responden mempunyai tingkat sikap hukum yang relatif kurang setuju terhadap kepemilikan akta perkawinan, dan sejumlah 23 $(76,67 \%)$ responden mempunyai tingkat sikap hukum yang relatif setuju terhadap kepemilikan akta perkawinan.

Berdasarkan data tersebut diatas dapat diambil kesimpulan bahwa sebagian besar masyarakat Banjar Pasti, Desa Pandak Gede, Kabupaten Tabanan memiliki sikap hukum yang relatif setuju terhadap kepemilikan akta perkawinan. Apabila dihubungkan data dalam tabel 5 dengan data pada tabel 3 dan 4, maka dapat diinterpretasikan bahwa sikap hukum setuju masyarakat terhadap kepemilikan akta perkawinan didasarkan pada pemahaman hukum dan pengetahuan hukum masyarakat yang tinggi terhadap kepemilikan akta perkawinan.

Menurut Otje Salman, indikator ketiga dari kesadaran hukum adalah sikap hukum, yaitu suatu kecendrungan untuk menerima hukum karena adanya penghargaan terhadap hukum sebagai sesuatu yang bermanfaat atau menguntungkan jika hukum tersebut ditaati. Seseorang disini yang nantinya akan mempunyai kecendrungan untuk mengadakan penilaian tertentu terhadap hukum.

Kesadaran hukum masyarakat terhadap kepemilikan akta perkawinan, selain dilihat dari pengetahuan hukum, pemahaman hukum dan sikap hukum, juga dapat dilihat dari indikator pola perilaku hukum, maka diperoleh gambaran sebagaimana yang terdapat dalam tabel berikut :
Tabel 6: Pola perilaku hukum responden terhadap kepemilikan akta perkawinan.

\begin{tabular}{|c|c|c|c|}
\hline $\begin{array}{c}\text { Pola Perilaku } \\
\text { Hukum }\end{array}$ & Interval Klas & $\begin{array}{c}\text { Frekuensi } \\
(\mathrm{F})\end{array}$ & $\begin{array}{c}\text { Presentase } \\
(\%)\end{array}$ \\
\hline Tidak Sesuai & 6 & 3 & 10 \\
Kurang Sesuai & 7 & 0 & 0 \\
Sesuai & $8-9$ & 27 & 90 \\
\hline Jumlah & & 30 & 100 \\
\hline
\end{tabular}

Sumber: Data primer yang diolah.

Tabel 6 diatas menjelaskan bahwa dari seluruh responden sebanyak 30 orang, sejumlah $3(10 \%)$ responden mempunyai tingkat pola perilaku hukum yang relatif tidak sesuai terhadap kepemilikan akta perkawinan. Sejumlah $0(0 \%)$ mempunyai tingkat pola perilaku hukum yang relatif kurang sesuai terhadap kepemilikan akta perkawinan, dan sejumlah 27 (90\%) responden mempunyai tingkat pola perilaku hukum yang relatif sesuai terhadap kepemilikan akta perkawinan.

Berdasarkan data tersebut diatas dapat diambil kesimpulan bahwa sebagian besar masyarakat Banjar Pasti, Desa Pandak Gede, Kabupaten Tabanan memiliki tingkat pola perilaku hukum yang relatif sesuai terhadap kepemilikan akta perkawinan. Apabila dihubungkan data dalam tabel 6 dengan data pada tabel 3,4,5, maka dapat diinterpretasikan bahwa pola perilaku hukum masyarakat yang sesuai didasarkan pada sikap hukum yang setuju, pemahaman hukum yang tingggi dan pengetahuan hukum yang tinggi

Menurut Otje Salman, indikator keempat dari kesadaran hukum adalah pola perilaku hukum, yaitu dimana seseorang atau dalam suatu masyarakat warganya mematuhi peraturan yang berlaku. Indikator ini merupakan indikator yang paling utama, karena dalam indikator tersebut dapat dilihat apakah suatu peraturan berlaku atau tidak dalam masyarakat, sehingga seberapa jauh kesadaran hukum dalam masyarakat dapat dilihat dari pola perilaku hukum.

Berdasarkan data tersebut diatas, maka dapat disimpulkan bahwa kesadaran hukum masyarakat Banjar Pasti, Desa Pandak Gede, Kabupaten Tabanan relatif tinggi. Hal ini dapat dibuktikan dengan indikator pengetahuan hukum yang tinggi, pemahaman hukum yang tinggi, sikap hukum yang setuju dan pola perilaku hukum yang sesuai terhadap kepemilikan akta perkawinan. 
Artinya semakin tinggi tingkat masing-masing indikator dari masyarakat tersebut diatas, maka semakin tinggi pula tingkat kesadaran hukum masyarakat Banjar Pasti, Desa Pandak Gede, Kabupaten Tabanan.

\section{B. Faktor-Faktor yang Mempengaruhi Kesadaran Hukum Masyarakat Di Banjar Pasti terhadap Kepemilikan Akta Perkawinan berdasarkan Undang Perkawinan.}

Adapun faktor-faktor yang mempengaruhi kesadaran hukum masyarakat di banjar Pasti yaitu: 1.Faktor Pendidikan

Berdasarkan ketentuan Pasal 1 angka (1) Undang-Undang Nomor 20 Tahun 2003 tentang Sistem Pendidikan Nasional, Pendidikan adalah usaha sadar dan terencana untuk mewujudkan suasana belajar dan proses pembelajaran agar peserta didik secara aktifmengembangkan potensi dirinya untuk memiliki kekuatan spiritual keagamaan, pengendalian diri, kepribadian, kecerdasan, akhlak mulia, serta keterampilan yang diperlukan dirinya, masyarakat, bangsa dan negara.

Pendidikan nasional berfungsi mengembangkan kemampuan dan membentuk watak serta peradaban bangsa yang bermartabat dalam rangka mencerdaskan kehidupan bangsa, bertujuan untuk berkembangnya potensi peserta didik agar menjadi manusia yang beriman dan bertakwa kepada Tuhan Yang Maha Esa, berakhlak mulia, sehat berilmu, cakap, kreatif, mandiri, dan menjadi warga negara yang demokratis serta bertanggung jawab. (Pasal 3 Undang-Undang Nomor 20 Tahun 2003 tentang Sistem Pendidikan Nasional).

Berdasarkan Pasal 1 angka (11) UndangUndang Nomor 20 Tahun 2003 tentang Sistem Pendidikan Nasional, menyebutkan bahwa Pendidikan Formal adalah jalur pendidikan yang terstruktur dan berjenjang yang terdiri atas pendidikan dasar, pendidikan menengah, dan pendidikan tinggi. Tingkat pendidikan pada umumnya berawal dari pendidikan Sekolah Dasar (yang sering disebut dengan istilah SD). Kemudian beralih pada pendidikan di Sekolah Menengah Pertama atau Sekolah Lanjutan Tingkat Pertama (yang sering disebut dengan istilah SMP atau SLTP). Setelah itu lanjut pada pendidikan Sekolah
Menengah Atas (atau yang sering disebut SMA). Pada umumnya, wajib belajar dalam pendidikan adalah sembilan tahun. Setelah pendidikan tingkat SMA dapat dilanjutkan ke jenjang yang lebih tinggi, yaitu Perguruan Tinggi.

Hubungan antara faktor pendidikan dengan kesadaran hukum, yaitu dengan semakin tingginya tingkat pendidikan seseorang, maka kecenderungan untuk sadar akan hukum terkadang lebih tinggi dibandingkan dengan tingkat pendidikan yang lebih rendah. Namun, tidak menutup kemungkinan seseorang yang tingkat pendidikannya rendah juga memiliki kesadaran hukum. Perbedaan tingkat pendidikan tersebut akan memberikan corak perilaku yang berbeda dalam memecahkan setiap permasalahan dalam kehidupan.

Dari data yang diperoleh dilapangan, dapat diketahui tingkat pendidikan masyarakat di Banjar Pasti yang dapat dilihat dari tabel berikut : Tabel 7 : Tingkat Pendidikan Responden

\begin{tabular}{|c|c|c|}
\hline Tingkat Pendidikan & Frekuensi (F) & Presentase (\%) \\
\hline SD & 3 & 10 \\
\hline SMP & 4 & 13,33 \\
\hline SMA & 20 & 66,67 \\
\hline PT & 3 & 10 \\
\hline Jumlah & 30 & 100 \\
\hline
\end{tabular}

Sumber : Data primer yang diolah.

Dari tabel 7 diatas dapat diketahui bahwa dari sebanyak 30 responden menunjukkan 3(10\%) responden mempunyai tingkat pendidikan SD (Sekolah Dasar), sebanyak 4 (13,33\%) responden mempunyai tingkat pendidikan SMP (Sekolah Menengah Pertama), sebanyak 20 (66,67\%) responden mempunyai tingkat pendidikan SMA (sekolah Menengah Atas) dan sebanyak 3 (10\%) responden mempunyai tingkat pendidikan PT (Perguruan Tinggi).

Tingkat pendidikan tersebut diatas berpengaruh terhadap tingkat kesadaran hukum masyarakat di Banjar Pasti. Sebagaimana telah diketahui bahwa masyarakat di Banjar Pasti memiliki tingkat kesadaran hukum yang tinggi $83,33 \%$.

\section{Faktor Umur}

Menurut Kamus Besar Bahasa Indonesia, kata umur memiliki arti yaitu lama waktu hidup atau ada (sejak dilahirkan atau diadakan). Dari 
penelitian yang dilakukan dapat diketahui umur dari masing-masing responden, yang dapat diketahui dari tabel dibawah ini :

Tabel 8 : Umur dari Responden

\begin{tabular}{|c|c|c|}
\hline Umur (Thn.) & Frekuensi (F) & Presentase (\%) \\
\hline $21-30$ & 5 & 16,67 \\
\hline $31-40$ & 11 & 36,67 \\
\hline $41-50$ & 10 & 33.33 \\
\hline $51-60$ & 4 & 13,33 \\
\hline Jumlah & 30 & 100 \\
\hline
\end{tabular}

Sumber: Data primer yang diolah.

Dari tabel 8 tersebut diatas, dapat diketahui bahwa dari 30 responden yang ada sejumlah $5(16,67 \%)$ responden berumur 21-30 tahun, sejumlah $11(36,67 \%)$ responden berumur 31-40 tahun, sejumlah $10(33,33 \%)$ responden berumur 41-50 tahun, dan sejumlah 4(13,33\%) responden berumur 51-60 tahun.

Tingkat umur tersebut diatas berpengaruh terhadap tingkat kesadaran hukum masyarakat di Banjar Pasti. Sebagaimana telah diketahui bahwa masyarakat di Banjar Pasti memiliki tingkat kesadaran hukum yang tinggi $83,33 \%$.

\section{Faktor Jenis Kelamin}

Menurut Kamus Besar Bahasa Indonesia Jenis Kelamin dapat dibedakan menjadi laki-laki atau perempuan. Berdasarkan hasil wawancara dengan Kelian Dinas Banjar Pasti, penduduk Banjar Pasti berjumlah 410 Jiwa, yang mana lakilaki berjumlah 192 Jiwa dan Perempuan berjumlah 218 Jiwa. Dari penelitian yang dilakukan dapat diketahui Jenis kelamin dari masing-masing responden, yang dapat diketahui dari tabel dibawah ini :

Tabel 9 : Jenis Kelamin Responden.

\begin{tabular}{|c|c|c|}
\hline Jenis Kelamin & Frekuensi (F) & Presentase (\%) \\
\hline Laki-laki & 13 & 43,33 \\
\hline Perempuan & 17 & 56,67 \\
\hline Jumlah & 30 & 100 \\
\hline
\end{tabular}

Sumber : Data primer yang diolah.

Dari tabel 9 tersebut diatas, dapat diketahui bahwa dari 30 responden sejumlah 13 $(43,33 \%)$ responden berjenis kelamin laki-laki dan $17(56,67 \%)$ responden berjenis kelamin perempuan.

Jenis Kelamin dari masing-masing responden tersebut diatas berpengaruh terhadap tingkat kesadaran hukum masyarakat di Banjar Pasti. Sebagaimana telah diketahui bahwa masyarakat di Banjar Pasti memiliki tingkat kesadaran hukum yang tinggi $83,33 \%$

\section{KESIMPULAN DAN SARAN}

\section{A. Kesimpulan}

Berdasarkan hasil penelitian tersebut diatas, dapat diambil kesimpulan sebagai berikut: 1. Tingkat kesadaran hukum masyarakat Di Banjar Pasti terhadap kepemilikan akta perkawinan berdasarkan Undang-Undang Nomor 1 Tahun 1974 tentang Perkawinan relatif tinggi. Hal ini dapat dibuktikan dengan indikator-indikator sebagai berikut :

a. Tingginya tingkat pengetahuan hukum masyarakat di Banjar Pasti terhadap kepemilikan akta perkawinan.

b. Tingginya tingkat pemahaman hukum masyarakat di Banjar Pasti terhadap kepemilikan akta perkawinan.

c. Tingginya tingkat sikap hukum masyarakat di Banjar Pasti terhadap kepemilikan akta perkawinan.

d. Tingginya tingkat pola perilaku hukum masyarakat di Banjar Pasti terhadap kepemilikan akta perkawinan.

2. Faktor-faktor yang mempengaruhi kesadaran hukum masyarakat di Banjar Pasti terhadap kepemilikan akta perkawinan berdasarkan Undang-Undang Nomor 1Tahun 1974 tentang Perkawinan yaitu : Tingkat Pendidikan, Umur dan Jenis Kelamin.

\section{B. Saran}

1. Bagi Pemerintah, agar melakukan penyuluhan - penyuluhan hukum kepada masyarakat terutama tentang peraturan perundangundangan yang berlaku di bidang Hukum Perkawinan. Sehingga dengan meningkatnya pengetahuan dan pemahaman masyarakat tentang peraturan perundang-undangan di Bidang Hukum Perkawinan, maka akan meningkatkan kesadaran hukum dari masyarakat. 
2. Bagi Masyarakat, diharapkan agar berperan aktif dalam mengikuti berbagai kegiatan yang berupaya untuk meningkatkan pengetahuan dan pemahaman masyarakat tentang Hukum Perkawinan.

\section{DAFTAR PUSTAKA}

\section{Buku}

Badan Pembinaan Hukum Nasional kementerian Hukum dan Hak Asasi Manusia RI., 2011, Dampak Penyuluhan Hukum Terhadap tingkat Kesadaran Hukum Masyarakat, Jakarta

HS, Salim, 2009, Pengantar Hukum Perdata Tertulis (BW), Sinar Grafika, Jakarta

Kuntjaraningrat, 1999, Kebudayaan, Metalitet \& Pembangunan, Gramedia, Jakarta

Manan, Abdul, 2006, Aneka Masalah Hukum Perdata di Indonesia, Kencana, Jakarta

Rafiq, Ahmad, 2013, Hukum Perdata Di Indonesia, PT. Raja Grafindo Persada, Jakarta

Rasyidi, Lili, 1982, Hukum Perkawinan dan Perceraian di Malaysia dan Indonesia, Reka Cipta, Bandung

Salman, Otje, 1993, Kesadaran Hukum Masyarakat Terhadap Hukum Waris, Alumni, Bandung

Soerjono Soekanto, 1982, Kesadaran Hukum dan Kepatuhan Hukum, CV. Rajawali, Jakarta

Soekanto, Soerjono dan Abdullah, mustafa, 1987, Sosiologi Hukum dalam Masyarakat, Rajawali Pers, Jakarta

Soemitro, Rony Hanitijo, 1998, Metode Penelitian Hukum dan Jurimetri, Ghalia Indonesia, Jakarta

Soetrisno Hadi, 1985, Metodologi Reseacrh Jilid II, Yayasan Penerbit Fakultas Psikologi UGM,Yogyakarta

Usman, Rachmadi, 2006, Aspek-Aspek Hukum Perorangan \& Kekeluargaan di Indonesia, Sinar Grafika, Jakarta

\section{Skripsi}

Digdani, Tanty Kusuma 2012, Kesadaran Hukum Masyarakat Dalam Pembuatan Surat Izin Mengemudi (SIM) C di Kelurahan Limbangan Wetan Kecamatan Brebes Kabupaten Brebes, Skripsi, Purwokerto

\section{Website}

http://bali.tribunnews.com/2016/01/11/beginiprosedur-pembuatan-akta-perkawinandi-denpasar, 30 Juni 2017

http://kediri.tabanankab.go.id/profil-desa/desapandak-gede/, 30 Juni 2017

Peraturan Perundang-Undangan

Undang-Undang Nomor 1 Tahun 1974 tentang Perkawinan

Peraturan Pemerintah Republik Indonesia Nomor 9 Tahun 1975 tentang Pelaksanaan Undang-Undang Nomor 1 Tahun 1974 tentang Perkawinan 